\title{
Microbiological analysis of bioaerosols collected from Hospital Emergency Departments and ambulances
}

\author{
Agata Bielawska-Drózd ${ }^{1, A-D}$, Piotr Cieślik ${ }^{1, A-D}$, Justyna Bohacz ${ }^{2, A-D}$, \\ Teresa Korniłłowicz-Kowalska ${ }^{2, C, E-F}$, Dorota Żakowska ${ }^{1, C-D}$, Michał Bartoszcze ${ }^{1, E-F}$, \\ Bożena Wlizło-Skowronek ${ }^{1, C-D}$, Izabela Winnicka ${ }^{3, A-B}$, Marek Brytan ${ }^{4, E-F}$, Leszek Kubiak ${ }^{3, A-B}$, \\ Ewa Skopińska-Różewska ${ }^{5, A, E-F}$, Janusz Kocik ${ }^{6, A, E-F}$ \\ ${ }^{1}$ Biological Threats Identification and Countermeasure Centre, Military Institute of Hygiene and Epidemiology, Puławy, \\ Poland \\ 2 Faculty of Agrobioengineering, Department of Environmental Microbiology, Laboratory of Mycology, University of Life \\ Sciences, Lublin, Poland \\ ${ }^{3}$ Laboratory of Epidemiology, Military Institute of Hygiene and Epidemiology, Warsaw, Poland \\ ${ }^{4}$ Department of Pharmacology and Toxicology, Military Institute of Hygiene and Epidemiology, Warsaw, Poland \\ ${ }^{5}$ Pathology Department, Biostructure Centrum, Medical University, Warsaw, Poland \\ ${ }^{6}$ School of Public Health, Centre for Postgraduate Medical Education, Warsaw, Poland \\ A - Research concept and design, B - Collection and/or assembly of data, C - Data analysis and interpretation, \\ $D$ - Writing the article, $E$ - Critical revision of the article, $F$ - Final approval of article
}

\begin{abstract}
Bielawska-Drózd A, Cieślik P, Bohacz J, Korniłłowicz-Kowalska T, Żakowska D, Bartoszcze M, Wlizło-Skowronek B, Winnicka I, Brytan M, Kubiak L, Skopińska-Różewska E, Kocik J. Microbiological analysis of bioaerosols collected from Hospital Emergency Departments and ambulances. Ann Agric Environ Med. 2018; 25(2): 274-279. doi: 10.26444/aaem/80711
\end{abstract}

\begin{abstract}
Introduction and objective. The goal of the study was a microbiological, qualitative and quantitative analysis of bioaerosol at the workplace of medical personnel (Health Emergency Departments (HEDs), ambulances), and comparative administration offices with an expected neutral occupational exposure to biological agents measured with individual Button Sampler.

Materials and method. Personal sampling was performed with Button Sampler instrument loaded with gelatine filters in 10 HEDs, in 9 ambulances and in 9 offices to assess the occupational biological agents' exposure in air. Sampling was conducted from March until April 2016. Samples were quantitatively assessed for viable and total number of bacteria and fungi. Routine procedures for microbiological diagnostics were implemented. Data were analysed using Kruskal-Wallis and Mann-Whitney statistical tests with $a=0.05$. P value less than 0.05 were considered significant.

Results. At the workplaces assessed, the concentrations of viable microorganisms in HEDs were $1.3 \times 10^{2}-4.2 \times 10^{3}$ $\mathrm{CFU} / \mathrm{m}^{3}$ for bacteria, $3.4 \times 100-8.1 \times 10^{1} \mathrm{CFU} / \mathrm{m}^{3}$ for fungi; in ambulances $1.3 \times 10^{2}-1.4 \times 10^{3} \mathrm{CFU} / \mathrm{m}^{3}$ (bacteria), $6.7 \times 10^{0}-$ $6.5 \times 10^{2} \mathrm{CFU} / \mathrm{m}^{3}$ (fungi) and in offices $4.2 \times 10^{1}-5.0 \times 10^{3} \mathrm{CFU} / \mathrm{m}^{3}$ (bacteria), $0-7.9 \times 10^{2} \mathrm{CFU} / \mathrm{m}^{3}$ (fungi). In outdoor air, the number of microorganisms reached the level: $1.0 \times 10^{2}-5.9 \times 10^{2} \mathrm{CFU} / \mathrm{m}^{3}$ for bacteria and $1.5 \times 10^{2}-8.2 \times 10^{2} \mathrm{CFU} / \mathrm{m}^{3}$ for fungi. The predominant isolated bacteria were Gram-positive cocci. The prevalent fungi species belonged to the genus Aspergillus and Penicillium.

Conclusions. The quantitative assessment of examined indoor air was similar to control outdoor air, and were relatively low. The level of microbiological contamination did not exceed $5 \times 10^{3} \mathrm{CFU} / \mathrm{m}^{3}$ which is recommended as an admissible level in public spaces in Poland.
\end{abstract}

\section{- Key words}

Button Sampler, bioaerosol, Hospital Emergency Departments, ambulances, bacteria, fungi

\section{INTRODUCTION}

The sanitary and hygienic status of ambulances and Hospital Emergency Departments (HEDs) in Poland is systematically evaluated by the appropriate sanitary services [1]. The monitoring involves analysing the status of work surfaces used by health professionals in the course of their duty. There exists, however, a potential threat posed by harmful biological agents dispersed by the air. Therefore analysis of

Address for correspondence: Agata Bielawska-Drózd, Biological Threats Identification and Countermeasure Center, Military Institute of Hygiene and Epidemiology, Puławy, Lubelska 2 St., Poland, Lubelska 2, 24-100 Puławy, Poland E-mail: abielawska@wihe.pulawy.pl

Received: 12.10.2017; accepted: 21.11.2017; first published: 25.01.2018 bacterial and fungal bioaerosols is a significant element of ensuring appropriate health and safety conditions for both medical personnel and patients $[2,3,4,5,6,7,8]$. The analysis of an individual exposure of HEDs staff should be based on a personal sampling device in order to achieve a high degree of accuracy in the assessment of threat level. The aim of this study was to evaluate microbiological contamination at the workplaces of medical personnel - HEDs and ambulances, and in the administration offices (as a control) by harmful biological agents with the use of a personal sampling device (Button Sampler, SKC Ltd., Pennsylvania, USA). 


\section{MATERIALS AND METHOD}

Air samples were collected in selected hospitals, ambulances and hospital administration offices in Warsaw, Poland. A total of 28 samples were collected from the workstations of HEDs personnel (10 samples), ambulance rescue workers (9 samples) and hospital administration staff (9 samples). The sampling was performed during March - April 2016, with an average outdoor temperatures of $0-15^{\circ} \mathrm{C}$ and humidity between $50-80 \%$. The sampling was conducted in locations with a variety of ventilation systems (gravitational, HEPA filtration and air conditioning); the Polish standard PNEN 13098, regulating indoor air quality management, was adhered to at all times.

Air analysis was carried out by filtration, where particles suspended in the air were collected and deposited onto a porous medium (gelatine filter with the pore diameter $3 \mu \mathrm{m}$ ); the process utilised a personal Button Sampler (SKC Ltd., Pennsylvania, USA) with the air flow set at the level of $4 \mathrm{~L} / \mathrm{min}$ $\left(\max .720 \mathrm{~L}=0.72 \mathrm{~m}^{3}\right)$ and sampling duration between $1-3$ hours, depending on individual availability of the hospital workers. The equipment was calibrated using the device Coley DEM 2000 (USA, TSI, Model 4043E). The samples were transported in cool conditions, at the temperature of $4-8^{\circ} \mathrm{C}$; the time elapsed between sampling and arrival at the laboratory was between 24-36 hours.

The material for analysis was a liquid suspension from the gelatine filters used. The filters were transferred to sterile test tubes in aseptic conditions and then dissolved in $8 \mathrm{ml}$ of sterile, deionised water with $0.01 \%$ Tween 80 added. The liquidized material was divided into 2 parts for mycological and bacteriological analyses. The microbiological analysis was conducted according to microbiological standards and followed the principles of good laboratory practice.

In order to determine the total number of culture microorganisms, in compliance with the Polish standard PN-EN 13098, appendix C, the following culturing media were used: nutrient agar (Graso Biotech, Poland) for the total number of bacteria and (Malt extract LAB-AGAR (MEA) (Biocorp) to find the numbers of yeasts and filamentous fungi. Streptomycin $\left(30 \mathrm{mg} / \mathrm{dm}^{3}\right)$ and chlortetracycline $\left(2 \mathrm{mg} / \mathrm{dm}^{3}\right)$ were added to the maltose medium.

To find the number of bacteria and fungi in each sample, several 10 -fold dilutions were prepared $\left(10^{-1}, 10^{-2}\right)$ with sterile deionised water, after which the culturing media were inoculated by the spread plate technique using $0.1 \mathrm{ml}$ (for bacteria) and the pour plate technique using $1.0 \mathrm{ml}$ (for fungi) of each dilution (from $10^{0}$ to dilutions $10^{-1}$ and $10^{-2}$ ) in 3 repetitions. The samples for bacteria were incubated at the temperature of $37^{\circ} \mathrm{C}$ for $2-7$ days, and subsequently the colony-forming units were calculated $\left(\mathrm{CFU} / \mathrm{m}^{3}\right)$ according to the formula shown in appendix D.1 of the Polish standard PN-EN 13098. The samples for fungi were incubated at the temperature of $26^{\circ} \mathrm{C}$ for $4-7$ days, after which the colonies formed were counted and the number of colony forming units $\left(\mathrm{CFU} / \mathrm{m}^{3}\right)$ was calculated according to the formula shown in the appendix D.1 of the Polish standard PN-EN 13098.

Identification of the bacteria was performed according to the generally accepted procedures of microbiological diagnostics, using the culturing methods, bacterioscopy, latex tests and biochemical identification (appropriate ID cards: GP, GN, ANC, BCL (bioMerieux, France) with the use of an automatic system Vitek2 Compact (bioMerieux,
France), and following the manufacturer's recommendations.

The obtained colonies of fungi (pure cultures) were transferred onto slants of PDA medium (Potato dextrose agar) and incubated at $26^{\circ} \mathrm{C}$ for $1-2$ weeks. Pure culture were used for species identification.

Identification was based on the macroscopic observation on agar slants and plates and microscopic observation in micro-cultures (PDAs, Czapek-Dox medium for Penicillium and Aspergillus). The micro-cultures were incubated at the temperature of $26^{\circ} \mathrm{C}$ for 3-7 days. In macroscopic observations, the colouring of mycelium, its structure and pigmentation were taken into consideration. The microscopy analysis involved observations of the structure of the vegetative mycelium and conidia. The final classification was based on the taxonomy publications by Domsch et al., Barnett and Hunter, Watanabe, Ellis and Krzyściak et al. [9, $10,11,12,13]$. The species names of the fungi were verified on the basis of the Index Fungorum [14]. The criteria adopted for the biosafety of fungi potentially pathogenic for humans, was according to the European Confederation of Medical Mycology (ECMM) [15].

Statistical analysis. The normal distribution of data was analysed using the Shapiro-Wilk test. Differences shown in the results were described using the tests of KruskalWallis $(\alpha=0.05)$ and Mann-Whitney $(\alpha=0.05)$ (http://www. socscistatistics.com).

\section{RESULTS}

The average concentration ( $\mathrm{Me}$ - Median) of bioaerosols tested by individual sampling in selected workplaces was as follows: for HEDs' personnel $-4.7 \times 10^{2} \mathrm{CFU} / \mathrm{m}^{3}$ (bacteria), $6.7 \times 10^{\circ} \mathrm{CFU} / \mathrm{m}^{3}$ (fungi); for ambulances' personnel $-3.0 \times 10^{2}$ $\mathrm{CFU} / \mathrm{m}^{3}$ (bacteria), $4.7 \times 10^{1} \mathrm{CFU} / \mathrm{m}^{3}$ (fungi); in hospital administration offices spaces $-2.3 \times 10^{2} \mathrm{CFU} / \mathrm{m}^{3}$ (bacteria), $2.4 \times 10^{1} \mathrm{CFU} / \mathrm{m}^{3}$ (fungi). The average concentration of bioaerosols in outdoor air was $2.2 \times 10^{2} \mathrm{CFU} / \mathrm{m}^{3}$ for bacteria and $3.2 \times 10^{2} \mathrm{CFU} / \mathrm{m}^{3}$ for fungi.

In the tested places (HEDs, ambulances and hospital administration office spaces) the range of concentrations of bacterial and fungal bioaerosols showed the values presented in Table 1.

Table 1. Comparison of bacterial and fungal concentrations in different workplaces with personal sampler

\begin{tabular}{lcccc}
\hline \multirow{2}{*}{ Workplaces } & \multicolumn{2}{c}{ BACTERIA $\left(\mathrm{CFU} / \mathrm{m}^{3}\right)$} & \multicolumn{2}{c}{ FUNGI $\left(\mathrm{CFU} / \mathrm{m}^{3}\right)$} \\
\cline { 2 - 5 } & Conc. Range & Median & Conc. Range & Median \\
\hline HEDs $(\mathrm{N}=10)$ & $1.3 \times 10^{2}-4.2 \times 10^{3}$ & $4.7 \times 10^{2}$ & $3.4 \times 10^{0}-8.1 \times 10^{1}$ & $6.7 \times 10^{0}$ \\
\hline AMBULANCES $(\mathrm{N}=9)$ & $1.3 \times 10^{2}-1.4 \times 10^{3}$ & $3.0 \times 10^{2}$ & $6.7 \times 10^{0}-6.5 \times 10^{2}$ & $6.7 \times 10^{1}$ \\
\hline OFFICES $(\mathrm{N}=9)$ & $4.2 \times 10^{1}-5.0 \times 10^{3}$ & $2.3 \times 10^{2}$ & $0-7.9 \times 10^{2}$ & $2.4 \times 10^{1}$ \\
\hline OUTDOOR AIR $(\mathrm{N}=13)$ & $1.0 \times 10^{2}-5.9 \times 10^{2}$ & $2.2 \times 10^{2}$ & $1.5 \times 10^{2}-8.2 \times 10^{2}$ & $3.2 \times 10^{2}$
\end{tabular}

Kruskall-Wallis test for bacteria: $p=0.1971(a=0.05)$ - differences not statistically significant Kruskall-Wallis test for fungi: $p=0.0001(a=0.05)$ - differences statistically significant

Qualitative analysis of bacterial and fungal bioaerosols showed a variety of genera and species (Tab. 2). Several dominant bacterial groups were determined, i.e. Grampositive cocci and endospore-forming Gram-positive bacilli (Fig. 1). Among all the microorganisms belonging to these groups: coagulase-negative Staphylococci, bacteria from 
Table 2. Numbers and percentages of bacterial and fungal strains identified in tested workplaces

Microorganisms

\section{Bacteria}

Gram-positive cocci

Staphylococcus epidermidis

Staphylococcus caprae

Staphylococcus hominis

Staphylococcus cohnii

Other CoNS**

Micrococcus luteus

Kocuria rosae

Kocuria kristinae

Nonsporing Gram-positive rods

Corynebacterium spp.

Endospore-forming Gram-positive bacilli

Bacillus spp.

Mesophilic actinomycetes

Actinomyces spp.

Gram-negative bacteria

Sphingomonas paucimobilis

Total

Filamentous fungi

Alternaria alternata (Fr.) Keissl

Alternaria tenuissima (Kunze) Wiltshire

Aspergillus brasiliensis Varga Frisvad \& Samson

Aspergillus flavus Link

Aspergillus fumigatus Fresen

Aspergillus nidulans (Eidam) G. Winter

Aureobasidium pullulans (de Bary \& Löwenthal), G. Arnaud

Bjerkandera adusta (Willd.) P.Karst.

Botrytis cinerea Pers.

Chaetomium cochliodes Palliser

Chaetomium sp.

dark-coloured sterile mycelium

Cladosporium cladosporoides (Fresen.) G.A.de Vries

Cladosporium herbarum (Pers.) Link

Cladosporium sp.

Clonostachys rosea (Link) Schroers, Samuels, Seifert \&W.Gams

Colletotrichum dematium (Pers.) Grove

Coniochaeta hoffmannii (J.F.H. Beyma) Z.U. Khan, Gené \& Guarro

Engyodontium album (Limber) de Hoog

Epicoccum nigrum Link

Lecanicillium lecanii (Zimm.) Zare\&W.Gams

Marielliottia dematioidea (Bubák \& Wróbl.) Schoemaker

Mucor plumbeus Bonord

Penicillium brevicompactum Dierckx

Penicillium canescens Sopp.

Penicillium chrysogenum Thom

Penicillium citrinum Thom

Penicillium decumbens Thom

Penicillium digitatum (Pers.) Sacc.

Penicillium expansum Link

Penicillium glabrum (Wehmer) Westling

Penicillium restrictum J.C. Gilman E.V. Abbot

Penicillium simplicissimum (Oudem.) Thom

Penicillium verrucosum Dierckx

Phomasp.

Pseudogymnoascus pannorum (Link) Minnis \& D.L. Lindner

Purpureocillium lilacinum (Thom), Luangs-ard, Houbraken, Hywel-Jones, Samson

Rhizopus stolonifera (Ehrenb.) Vuill.

Sarocladium bacillisporum (Onions \& G.L. Barron) Summerb

Scopulariopsis brumptii Salv.-Duval

Talaromyces piceae (Raper \& Fennell) Samson, N. Yimaz, Houbraken, Spierenburg, Seifert, Varga \& Frisvad

Talaromyces ruber (Stoll) N.Yilmaz, Houbraken, Frisvad \& Samson

Talaromyces rugulosus (Thom) Samson, N. Yilmaz, Frisvad \& Seifert

Trichoderma viride Pers

Nonsporing

Nonsporing hyaline

Total

*HEDs - Hospital Emergency Departments; **CoNS - Coagulase Negative Staphylococci

HEDs* Ambulances Offices Outdoor air $^{*}$ contribution to total microbiota (\%)

\begin{tabular}{cccc}
$1(4 \%)$ & 0 & $3(15 \%)$ & 0 \\
$1(4 \%)$ & 0 & 0 & 0 \\
$1(4 \%)$ & $3(15 \%)$ & 0 & 0 \\
$1(4 \%)$ & 0 & 0 & 0 \\
$4(17 \%)$ & $6(30 \%)$ & $5(25 \%)$ & $4(24 \%)$ \\
$4(17 \%)$ & $2(10 \%)$ & $4(20 \%)$ & $2(12 \%)$ \\
0 & $1(5 \%)$ & 0 & $1(6 \%)$ \\
$3(13 \%)$ & $1(5 \%)$ & 0 & $1(6 \%)$ \\
$4(17 \%)$ & $5(25 \%)$ & $1(5 \%)$ & $4(24 \%)$ \\
$3(13 \%)$ & $1(5 \%)$ & $3(15 \%)$ & $1(6 \%)$ \\
$2(8 \%)$ & 0 & $2(10 \%)$ & $2(12 \%)$ \\
\hline & & & \\
24 & $1(5 \%)$ & $2(10 \%)$ & $2(12 \%)$ \\
\hline
\end{tabular}

$\begin{array}{cccc}1(3 \%) & 0 & 0 & 0 \\ 0 & 0 & 0 & 1 \\ 0 & 3(3 \%) & 0 & 2(3 \%) \\ 5(13 \%) & 2(2 \%) & 95(82 \%) & 0 \\ 3(8 \%) & 4(4 \%) & 3(3 \%) & 20(29 \%)\end{array}$

$\begin{array}{cccc}0 & 0 & 0 & 1 \\ 0 & 1 & 0 & 0 \\ 2(5 \%) & 6(6 \%) & 0 & 5(7 \%) \\ 1(3 \%) & 2(2 \%) & 1 & 3(4 \%)\end{array}$

$\begin{array}{lllc}0 & 1 & 0 & 0 \\ 0 & 0 & 0 & 1\end{array}$

$1(3 \%) \quad 1 \quad 11 \frac{116 \%)}{}$

$\begin{array}{cccc}0 & 3(3 \%) & 1 & 0 \\ 1(3 \%) & 0 & 1 & 1\end{array}$

$\begin{array}{llll}0 & 0 & 1 & 0 \\ 0 & 1 & 0 & 0\end{array}$

$\begin{array}{llll}0 & 1 & 0 & 0 \\ 0 & 0 & 0 & 1\end{array}$

$\begin{array}{cccc}0 & 0 & 0 & 1 \\ 0 & 0 & 0 & 1 \\ 3(8 \%) & 6(6 \%) & 0 & 0\end{array}$

\begin{tabular}{cccc}
$3(8 \%)$ & $6(6 \%)$ & 0 & 0 \\
0 & 0 & 0 & 1 \\
1 & 0 & 0 & 0 \\
1 & 0 & 0 & 0 \\
1 & 0 & 0 & 0 \\
$2(5 \%)$ & 0 & 0 & 0 \\
0 & 1 & 0 & 0 \\
$2(5 \%)$ & $2(2 \%)$ & 0 & 0 \\
$2(5 \%)$ & 0 & 0 & 0 \\
0 & 0 & 1 & 0 \\
0 & 0 & 1 & 1 \\
1 & 0 & $2(2 \%)$ & 0 \\
\hline 1 & $56(58 \%)$ & 0 & $4(6 \%)$ \\
\hline 0 & 0 & 0 & 1 \\
\hline 1 & $2(2 \%)$ & 0 & 0 \\
$2(5 \%)$ & $2(2 \%)$ & $7(6 \%)$ & $5(7 \%)$ \\
\hline 0 & 1 & 0 & 0
\end{tabular}

\begin{tabular}{cccc}
0 & 1 & 0 & 0 \\
0 & 1 & 0 & 0 \\
1 & 0 & 0 & 0 \\
0 & 1 & 0 & 0 \\
0 & 0 & 0 & 1 \\
1 & 1 & 1 & 0 \\
\hline 1 & 0 & 0 & 0 \\
$2(5 \%)$ & 0 & 0 & 0 \\
1 & 0 & 0 & 0 \\
0 & 0 & 1 & 0 \\
\hline 1 & 0 & 0 & 0 \\
\hline 0 & 0 & 0 & $8(12 \%)$ \\
38 & 97 & 116 & 68 \\
\hline
\end{tabular}


the genera Micrococcus spp., Kocuria spp. and Bacillus spp. representing the Gram-positive endospore-forming bacilli dominated [Fig. 1, Tab. 2].

Statistical analysis with the Mann-Whitney $(\alpha=0.05)$ test of bacterial and fungal bioaerosol concentrations using individual samplers did not show statistically significant differences between workplaces in offices (offices vs. outdoor environment $\mathrm{p}>0.05$; ambulances vs. outdoor environment $p=0.204)$. However, differences were found between HEDs and the outdoor environment $(\mathrm{p}=0.0433)$. Also, comparing concentrations of bioaerosols in the tested workplaces did not show significant differences between HEDs and hospital administration offices ( $\mathrm{p} \geq 0.05$ ), between HEDs and ambulances. Statistically significant differences were found between office spaces and ambulances $(p=0.0466)$.

Comparison of fungal bioaerosol concentrations in outdoor spaces and the tested workplaces showed that fungal bioaerosol concentrations in the outdoor environment were significantly higher in HEDs, compared to the outdoor environment $(\mathrm{p} \leq 0.05)$; hospital administration offices vs. outdoor environment $(\mathrm{p}=0.00236)$; ambulances vs. outdoor environment $(\mathrm{p}=0.00132)$.

Qualitative analysis of fungal bioaerosols in the air of HEDs, ambulances and hospital administration office spaces showed the presence of 20 genera and 37 species of filamentous fungi (Tab. 2). Some of the most frequently found fungi belonged to Aspergillus (9-84\%) and Penicillium (9-65\%) genera; the remaining fungi constituted from 6-50\% [Fig. 2].

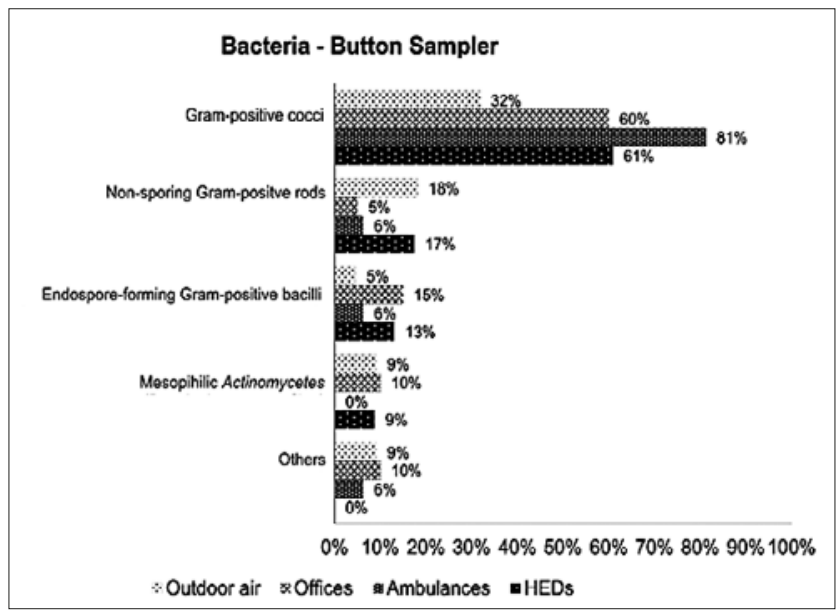

Figure 1. Percentage contribution of bacteria groups among tested workspaces Figure 2. Percentage contribution of fungi groups among tested workspaces



In the samples collected from the air of office spaces, the dominant fungus was Aspergillus flavus Link, constituting $82 \%$ of the total mycobiota. The largest percentage of Penicillium (65\%) was isolated from ambulances, 58\% of which belonged to Penicillium glabrum (Wehmer) Westling (former name Penicillium frequentans). Less numerous, below 9.3\%, were propagation units of the Aspergillus fumigatus Fresen (4\%), Bjerkandera adusta (Willd.) P. Karst. (6\%) and Engyodontium album (Limber) de Hoog (6\%) (former name Tritirachium album species). The remaining species constituted less than $3 \%$ of the isolated fungi population (Tab. 2, Fig. 1). The air of HEDs contained a low variety of fungi species (Tab. 2). Among the Aspergillus genus (21\% of all isolates), the predominant species were Aspergillus flavus and Aspergillus fumigatus, which constituted $13 \%$ and $8 \%$ (Tab. 2, Fig. 2) of the isolated strains, respectively. Also, the Penicillium genus was represented in $40 \%$ among the isolated fungi. The proportion of particular species was below $5 \%$.

The outdoor air samples collected in the proximity of the hospitals revealed 11 genera and 18 species of filamentous fungi. Mycological analysis of the outdoor air showed the presence of species similar to those found indoors; however, the presence of Aspergillus flavus was not detected. Aspergillus fumigatus constituted $29.8 \%$ of the total mycobiota isolated. Approximately $50 \%$ of the genera isolated did not belong to Aspergillus or Penicillium.

\section{DISCUSSION}

The results of testing were found to be within the range of concentrations presented by other authors for similar hospital locations $[6,16,17]$. The authors obtained the results for bioaerosols in different hospital rooms using the impact methods; for example, Mirzaei et al. studied HEDs spaces using an Andersen sampler and reported the bacterial bioaerosol pollution at the level of $1.03 \times 10^{2} \mathrm{CFU} / \mathrm{m}^{3}( \pm 33.84)$, while in surgery rooms the level was $6.33 \times 10^{1} \mathrm{CFU} / \mathrm{m}^{3}( \pm 32,94)$ [6]. Hoseinzadeh et al., in their research in hospital wards, showed average levels of bioaerosol concentrations of $1.6 \times 10^{2}$ $\mathrm{CFU} / \mathrm{m}^{3}$ (bacteria) and $1.25 \times 10^{1} \mathrm{CFU} / \mathrm{m}^{3}$ (fungi). Here, the sampling was carried out by filtration with MCES cellulose filters with the diameter of $0.45 \mu \mathrm{m}$ [5]. In a study in India using a personal sampler employing a filtration method with a gelatine filter in hospital wards, the results showed the range $3.7 \times 10^{3} \mathrm{CFU} / \mathrm{m}^{3}$ to $1.9 \times 10^{5} \mathrm{CFU} / \mathrm{m}^{3}$ for bacteria, 0 to $1.5 \times 10^{4}$ $\mathrm{CFU} / \mathrm{m}^{3}$ for fungi [18].

Analyses of the microbiological status of hospital office spaces have also been undertaken by several authors. Their results revealed the concentration level of bacterial and fungal bioaerosol to be from $10^{1}-10^{2} \mathrm{CFU} / \mathrm{ml}$. The results obtained in the presented study indicate the trends presented by other authors $[19,20,21]$.

The level of threat posed by bioaerosols to medical personnel in ambulances is not frequently discussed in the literature. One study presenting the subject was by Luksamijarulkul and Pipitsangjan, in which the bioaerosol concentrations for bacteria were $4.68 \times 10^{2} \pm 6.07 \times 10^{2} \mathrm{CFU} / \mathrm{m}^{3}$ and for fungi $-6.56 \times 10^{2} \pm 6.12 \times 10^{2} \mathrm{CFU} / \mathrm{m}^{3}$, as sampled in ambulances during the work of paramedics [8].

Due to the lack of legal regulations regarding the concentrations of harmful biological agents, the microbiological evaluation of tested workspaces was based 
on the values recommended by the Panel of Experts of the Interdepartmental Commission for Maximum Admissible Concentrations and Intensities for Agents Harmful to Health in the Working Environment [22]. The concentration values in the presented study did not exceed the recommended admissible values $\left(5 \times 10^{3} \mathrm{CFU} / \mathrm{m}^{3}\right.$ for bacteria and fungi).

The results of quality analysis of microorganisms in the current study showed analogous groups of microorganisms occurring in the tested workspaces: Hospital Emergency Departments, ambulances and hospital administration office spaces. The diversity of groups/genera/species of bacteria in the spaces tested was comparable. The group most commonly found was Gram-positive cocci (mainly coagulase-negative Staphylococci, Micrococcus and Kocuria spp.).

Analysis of genus composition of fungi isolated from the air of HEDs, ambulances and hospital office spaces showed a large variety of the genera present. This study showed a similarity between the fungal species found in- and outdoors; the numbers of species found in the air of hospital office spaces and in ambulances were higher than the number found in outdoor air. The genera most common in the air of office spaces, ambulances and HEDs were: Aspergillus (9.3 - 85\%) and Penicillium (9.5\% - 65\%) [23]. Similar results were reported by Luksamijarulkul and Pipitsangjan [8]. Yang and Mekiln et al. state that the presence of these fungi, analogously with Cladosporium, indicates humidity problems, particularly in indoor air. Among the species from these genera they mention Aspergillus versicolor, Aspergillus fumigatus and Aspergillus brasiliensis (former name Aspergillus niger) and genus Cladosporium [23, 24]. Flannigan, Dutkiewicz et al. and Rainer et al. declare that fungi present in humid indoor spaces may be responsible for asthma and/or hay fever and alveolitis alergica [25, 26, 27]. These fungi may also be the cause of immunotoxicity [28, 29]. The fungi posing the largest threat to human health and found in the air samples tested were the following species: Aspergillus fumigatus and Aspergillus flavus. Both species belong to opportunistic fungi usually causing infection in immunocompromised hosts. According to the criteria of ECMM [15], Aspergillus flavus and Aspergillus fumigatus may be classified as a risk category 2 agent (required BSL2Biosefty Level Laboratory 2). The fungi mentioned are supported by high air humidity and temperature. From the ecological viewpoint, they are classified as thermophilic or thermotolerant, with high water requirements; in particular, Aspergillus fumigatus needs a water activity (aw) level of at least $0.9-0.95$ in order to develop [30, 31]. Hedayati et al. state that the presence of Aspergillus flavus in hospitals is determined by the construction and maintenance level of the buildings and the conditions in the surrounding area [32]. Moreover, Yang emphasises that these species of fungi, analogously with others belonging to the genus Penicillium, are transported indoors from the outside environment [23]. This claim may explain the presence in large amount of these fungi in ambulances (65\%) and HEDs (40\%). The presence in offices of the genera Trichoderma and Chaetomium, next to the abundant Penicillium and Aspergillus, also suggests a high level of humidity. Trichoderma and Chaetomium grow in environments with high humidity; they are classified as hydrophilic fungi belonging to so-called tertiary colonizers and require a water activity of about 0.9-0.95 [33]. The large presence of Aspergillus flavus in the air of office spaces may result from poor decontamination. Luksamijarulkul and Pipitsangjan report that bacterial and fungal counts surpassing $500 \mathrm{CFU} / \mathrm{m}^{3}$ in the workplace is an indicator of deficient ventilation and inadequate sanitary conditions [8].

The proportion of particular groups of bacterial and fungal bioaerosols in relation to the total microbiota isolated from samples did not differ from common trends $[5,6,8,16,18$, 19, 20, 21].

Sampling techniques (stationary, individual), methods of bioaerosol collection (impact, liquid absorption, filtration), types of filters used, environmental conditions (weather: temperature, humidity, wind speed), technical conditions at the workspaces tested (varied ventilation and air-conditioning systems), and population density at the locations tested, may influence the quantity and quality of the tested bioaerosols. Also, after Aizenberg et al., the uniformity of the particle deposition on the filter of a Button Areosol Sampler is conductive to the accuracy of collection and the counting of microorganisms in the air samples tested, including fungal spores [33].

\section{CONCLUSIONS}

Concentrations of bacterial and fungal bioaerosols in individual sampling of the tested workspaces were lower than the levels for fungi and bacteria $\left(5 \times 10^{3} \mathrm{CFU} / \mathrm{m}^{3}\right)$ admissible in public spaces, as recommended by the Panel of Experts of the Interdepartmental Commission for Maximum Admissible Concentrations and Intensities for Agents Harmful to Health in the Working Environment. However, the microbiological working environment monitoring should be continued also in different seasons.

\section{REFERENCES}

1. National, Sanitary Inspectorate, Country Sanitary Conditions Reports, 2009-2011. [In Polish]

2. Charkowska A. Wydawnictwo Instytutu Ogrzewnictwa i Wentylacji PW, Warszawa, 1996. [In Polish]

3. Górny RL. Biohazards: standards, guidelines, and proposals for threshold limit values. Pod Met Oceny Środ Pracy. 2004; (3): 17-39.

4. Ekhaise FO, Ighosewe OU, Ajakpovi OD. Hospital indoor airborne microflora in private and government owned hospitals in Benin City Nigeria. World J Med Sci. 2008; 3(1): 19-23.

5. Hoseinzadeh E, Samarghandie MR, Ghiasian SA, Alikhani MY, Roshanaie G. Evaluation of bioaerosols in five educational hospitals wards air in Hamedan, during 2011-2012. Jundishapur J Microbiol. 2013; 6(6): e10704. http://doi.org/10.5812/jjm 10704. [cited 2.10.2017].

6. Mirzaei R, Shahriary E, Qureshi MI, Rakhshkhorshid A, Khammary A, Mohammadi M. Quantitative and qualitative evaluation of bio-aerosols in surgery rooms and emergency department of an educational hospital. Jundishapur J Microbiol. 2014; 7(10): e11688. http://doi.org/10.5812/ jjm.11. [cited 2.10.2017].

7. Gołofit-Szymczak M, Ławniczek-Wałczyk A, Górny RL. Pod Met Oceny Środ Pracy. 2013; 76(2): 5-17.

8. Luksamijarulkul P, Pipitsangjan S. Microbial air quality and bacterial surface contamination in ambulances during patient services. Oman Med J. 2015; 30(2): 104-110. http://doi.org/10.5001/omj.20. [cited 13.09.2017].

9. Domsch KH, Gams W, Anderson TH. Compendium of soil fungi (Vol. 1). London Academic Press, 1980.

10. Barnett HL, Hunter BB. Illustrated Genera of Imperfect Fungi. St. Paul Minnesota APS Press, 1998.

11. Watanabe T. Pictorial atlas of soil and seed fungi. 3rd ed. CRC Press, Taylor and Francis Group 2010; http://doi.org/10.1201/ebk143. [cited13.09.2017].

12. Ellis MB. Dematiaceous hyphomycetes. London Eastern Press, 1971. 
13. Krzyściak P, Skóra M, Macura AB. Atlas of human pathogenic fungi. Wrocław MedPharm, Poland, 2011; http://www.medpharm. pl. [cited13.09.2017]

14. Index Fungorum Organization, 2016; http://www.indexfungorum. org. [cited13.09.2017].

15. Hoog GS. Risk assessment of fungi reported from humans and animals. Mycoses. 1996; 39: 407-417.

16. Nourmoradi H, Amin MM, Hatamzadeh MI, Nikaeen M. Evaluation of bio-aerosols concentration in the different wards of three educational hospitals in Iran. Int J Environ Health Eng. 2012; 1(1): 47.

17. Özdemir M, Gündem NS, Baysal B. Investigation of bacterial counts in air at intensive care units and operating rooms. Anatol J Clin Investig. 2010; 4(1): 1-4.

18. Sudharsanam S, Swaminathan S, Ramalingam A, Thangavel G, Annamalai R, Steinberg R, et al. Characterization of indoor bioaerosols from a hospital ward in a tropical setting. African Health Sciences. 2012; 12(2): 217-225. http://doi.org/10.4314/ahs.v1. [cited 2.10.2017].

19. Wlazło A, Górny R L, Złotkowska R, Lawniczek A, Ludzeń-Izbińska B, Harkawy AS, et al. Workers' Exposure to Selected Biological Agents in Libraries of Upper Silesia. Med Pr. 2008; 59(2): 159-170.

20. Gołofit-Szymczak M, Górny RL. Bacterial and Fungal Aerosol in AirConditioned Office Buildings in Warsaw Poland - The Winter Season. Int J Occup Saf Ergon 2010; 16(4): 465-476.

21. Gołofit-Szymczak M, Górny RL, Ławniczek-Wałczyk A, Cyprowski M, Stobnicka A. Bacterial and fungal aerosols in the work environment of cleaners. Med Pr. 2014; 66(6): 779-791. https://doi.org/10.13075/ mp.58. [cited 2.10.2017].

22. Skowroń J, Górny R L. Szkodliwe czynniki biologiczne. W: Augustyńska D., Pośniak M. [red.]. CIOP-PIB, Warszawa; 2014, ss.181-190.

23. Yang CS. Fungi in the air: what do results of fungal air samples mean? EMLabP\&K. 2003; 1-3. https://www.emlab.com/media/re. [cited 13.09.2017].

24. Meklin T, Husman T, Vepsäläinen A, Vahteristo M, Koivisto J, HallaAho J, et al. Indoor air microbes and respiratory symptoms of children in moisture damaged and reference schools. Indoor Air. 2002; 12(3): 175-183. https://doi.org/10.1034/j.1600. [cited 2.10.2017].

25. Flannigan B. Air sampling for fungi in indoor environments. J Aerosol Sci. 1997; 28(3): 381-392. https://doi.org/10.1016/s0021. [cited 2.10.2017].

26. Dutkiewicz J, Cisak E, Sroka J, Wójcik-Fatla A, Zając V. Biological agents as occupational hazards-selected issues. Ann Agric Environ Med. 2011; 18(2): 286-293.

27. Rainer J, Peintner U, Pöder R. Biodiversity and concentration of airborne fungi in a hospital environment. Mycopathol. 2000; 149(2): 87-97.

28. Mishra SK, Ajello L, Ahearn DG, Burge HA, Kurup VP, Pierson D. Environmental mycology and its importance to public health. J. Med. Vet. Mycol. 1992; (supp1): 30, 287-305. https://doi.org/10.1080/026812. [cited 2.10.2017].

29. Robbins CA, Swenson LJ, Nealley ML, Kelman BJ, Gots RE. Health effect of mycotoxins in indoor air. J Occup Environ Hyg. 2000; 15(10): 773-784.

30. Grant C, Hunter CA, Flannigan B, Bravery AF. The moisture requirements of moulds isolated from domestic dwelling. Int Biodet. 1989; 25(4): 259-284. https://doi.org/10.1016/0265-3. [cited 2.10.2017].

31. Vujanovic V, Smoragiewicz W, Krzysztyniak K. Airborne fungal ecological niche determination as one of the possibilities for indirect mycotoxin risk assessment in indoor air. Environ Toxicol. 2001; 16(1): 1-8. http://doi.org/10.1002/1522-7. [cited 2.10.2017].

32. Hedayati MT, Pasqualotto AC, Warn PA, Bowyer P, Denning DW. Aspergillus flavus: human pathogen, allergen and mycotoxin producer. Microb. 2007; 153(6): 1677-1692. https://doi.org/10.1099/mic.0. [cited 2.10.2017].

33. Wang CH, Chen BT, Han BC, Liu ACY, Hung PC, Chen CY et al. Filed Evaluation of personal sampling methods for Multiple Bioaerosols. PLoS One. 2015; 10(3):e0120308.

34. Aizenberg V, Reponen T, Grinshpun SA, Willeke K. Performance of Air-O-Cell, Burkard, and Button Samplers for total enumeration of airborne spores. Am Ind Hyg Assoc J. 2000; 61(6): 855-864. http:// dx.doi.org/10.1080/1529. [cited 2.10.2017]. 